\title{
Supply Chain Management: A Study on Competitive Advantage Relationship and Operational Performance during Pandemic Covid 19 in Indonesia
}

\author{
Kenny Roz ${ }^{1}$ \\ ${ }^{1}$ Faculty Economics and Business, Management, University of Muhammadiyah Malang, Indonesia \\ Correspondence: Kenny Roz, Faculty Economics and Business, Management, University of Muhammadiyah \\ Malang, Indonesia.
}

Received: September 30, 2021

Accepted: November 1, $2021 \quad$ Online Published: November 5, 2021

doi:10.5539/ibr.v14n12p34

URL: https://doi.org/10.5539/ibr.v14n12p34

\begin{abstract}
This research was conducted to reveal the relationship between supply chain management, competitive advantage, and operational performance in coffee shops in Indonesia. The Data collection was obtained by distributing questionnaires online. The population in this study were business actors in the coffee sector, especially in the coffee shops in Indonesia. Determination of the sample in this study using non-probability because the population size cannot be identified. The sample of this study was 177 respondents. The research data were analyzed using path analysis techniques with analysis tools using Partial Least Square (PLS). The result found that SCM, competitive advantage has a significant positive effect on operational performance, SCM has a significant positive effect on competitive advantage, and competitive advantage is the perfect mediator for the effect of SCM has a significant positive effect on operational performance at a coffee shop in Indonesia.
\end{abstract}

Keywords: supply chain management, competitive advantage, operational performance, coffee shop

\section{Introduction}

Indonesia's commercial world is growing at a breakneck pace. One indicator of Indonesia's economic progress is the vast number of industrial and service industries. Because industry competition is becoming more intense, entrepreneurs must be able to deal with internal issues such as operational activities, finance, marketing, and business resources. Problems can develop not only from within the organization, but also from outside sources such as supplier selection, competitiveness, and customers. (Kumar et al., 2017). As competition becomes more tough, businesspeople must be able to execute proper business planning in accordance with company objectives. The Covid 19 pandemic has had a huge influence on the global economy, especially in the last year.

The Covid 19 epidemic has a wide range of effects in Indonesia, from tiny businesses to huge corporations. The enormity of the COVID-19 pandemic's impact resulted in a reduction in industrial operations, as well as permanent business closures. (Republika, 2020). It reveals that business players have adopted numerous new adaptations to survive the pressures induced by the impact of the Covid-19 epidemic, notably in the industrial sector, based on observations at the central Center Statistics Agency (BPS) in Indonesia. Implementing a competitive strategy in the company in order to win the market competition is one of the things that can be done to overcome the challenges that are being encountered. A supply chain management plan is one of the competitive strategies that businesses can apply. The integration of raw material procurement activities, services, and transformation activities into semi-finished items to final products, as well as delivery to clients, is known as supply chain management. (Heizer \& Render, 2014).

Furthermore, supply chain management is described as the administration of a company or organization's supply chain activities at a high level of excellence through cooperative organizational relationships, effective business processes, and information exchange. (Subhan \& Putro, 2017). Suppliers, which might include raw material suppliers, component and spare part suppliers, or semi-finished items (subassembly suppliers), producers of products and services, distributors, and finally the final customer are all actors in the business. Tjiptono, (2017) A competitive advantage, in addition to establishing the correct supply chain management strategy, can have an impact on a company's operational success. A competitive advantage, often known as a competitive advantage, is a company's capacity to stand out from the competition. When it comes to business competitiveness, competitive 
advantage is defined as a way to stand out from the competition. (Dikshit \& Trivedi, 2012; Marinagi et al., 2014). The use of a SCM approach to gain a competitive edge has been adopted in a variety of businesses, including the coffee shop.

The café is another term for a coffee shop, which is a location to eat and drink with a quick and easy menu and soft drinks for people who are relaxing, chatting, or having meetings with colleagues. The café shop was also picked as the best site for doing activities such as debates, teamwork, and simply keeping excellent relationships with coworkers. The coffee shop is a business that can be handled by a variety of different people in the business sector. This is backed up by the fact that Malang is one of Indonesia's most educational cities. A large number of newcomers in Indonesia, which is dominated by students, makes the coffee shop the right choice to gather. The relationship between supply chain management and competitive advantage on operational performance has been widely expressed empirically. Literature studies reveal that SCM and competitive advantage affect operational performance (Miguel \& Brito, 2011; Phan et al., 2019; Subhan \& Putro, 2017). Different things were revealed by (Fitrianto et al., 2016) Supply chain management does not have a complete impact on operational effectiveness, according to the study. Researchers are motivated to do additional research because of the differences in their findings. The researcher attempts to construct a conceptual framework based on the above information in order to determine the proposed hypothesis. Figure 1 is the conceptual framework of this research :

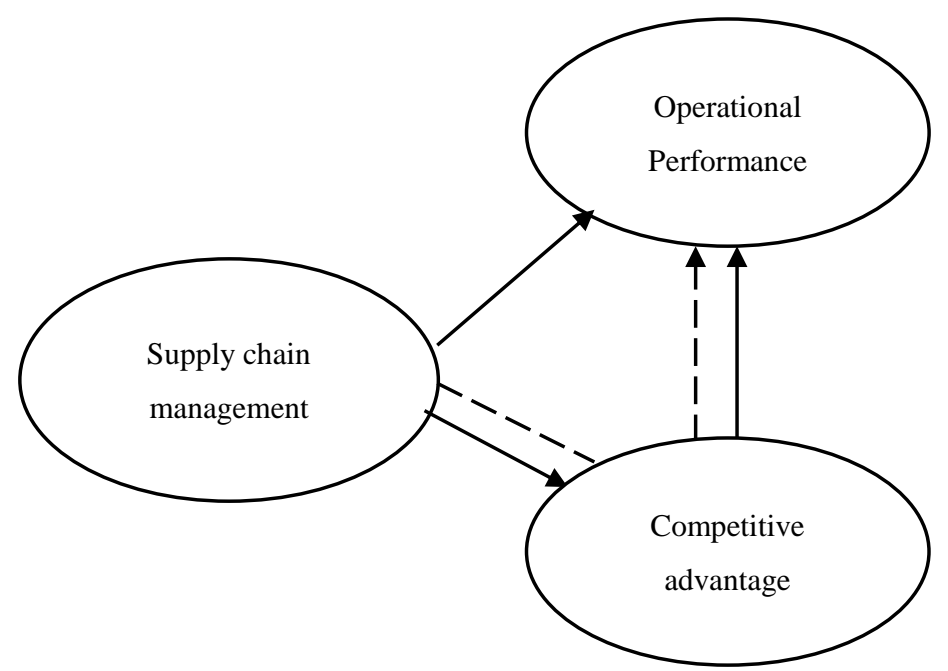

Figure 1. Research Conceptual Framework

Based on the conceptual framework presented in Figure 1, the researcher tries to make a hypothesis for this study. The hypotheses proposed in this study are as follows:

Hypothesis 1: SCM has a significant effect on Competitive Advantage at coffee shop.

Hypothesis 2: SCM has a significant effect on Operational Performance at a coffee shop.

Hypothesis 3: Competitive Advantage has a significant effect on Operational Performance at a coffee shop.

Hypothesis 4: SCM has a significant positive effect on Operational Performance through Competitive Advantage at the coffee shop.

The purpose of this study was to examine the effect of Supply Chain Management, Competitive Advantage on Operational Performance, both directly and indirectly after the Covid 19 pandemic at coffee shop in Indonesia.

\section{Method}

This research is a type of explanatory research, namely research that is based on a theory or hypothesis that will be used to test a phenomenon that occurs (Cooper \& Schindler, 2013). The primary motivation for doing this sort of explanatory research is to see if the given hypothesis can partially or completely explain the influence of the independent variable (supply chain management and competitive advantage) on the dependent variable (operational performance). The information was gathered through the use of an online questionnaire with a Likert scale of 1 to 5 . The population in this study were business actors in the coffee sector, especially in the coffee shop in Indonesia. Determination of the sample in this study using non-probability because the population 
size cannot be identified. As for determining the minimum number of samples with variable $\leq 5$, the sample size is 100 , while for variables $\leq 7$ the minimum is 150 , and variables $\geq 7$ are 300 (Hair et al., 2014).

Supply chain management variables are measured using 5 indicators (strategic supplier partnerships, customer relationships, information sharing levels, quality information sharing, and postponement) adapted from (Khaddam et al., 2020), Competitive advantage is measured using 5 indicators (price, quality, delivery dependability, product innovation, and time to market) which were adapted from research (Li et al., 2006), and operational performance was measured using 3 indicators (quality performance, cost, and delivery) which were adopted from research (Phan et al., 2019). This study uses SPSS version 25 software as a tool for data processing, and to test the research model using SEM Partial Least Square (PLS) with SmartPLS software. PLS is also used to measure the relationship of each indicator with its construct. In addition, PLS can also be used for confirmation purposes, such as hypothesis testing and exploration purposes.

\section{Results}

Based on the results of primary data collection using an online questionnaire, 177 respondents matched the criteria previously described by the researcher. The following are the demographics of the respondents presented in table 1 as follows:

Table 1. Demographics of Respondents

\begin{tabular}{lll}
\hline Information & Frequency & Percentage \\
\hline Gender & 123 & \\
Male & 54 & $69.49 \%$ \\
Female & & $30.51 \%$ \\
\hline Age & 45 & $25.42 \%$ \\
$20-23$ years old & 109 & $61.58 \%$ \\
$24-27$ years old & 23 & $12.94 \%$ \\
$>$ 27 tyears old & 68 & $38.41 \%$ \\
\hline Job Position & 109 & $61.59 \%$ \\
Owner / Manager & 34 & $19.20 \%$ \\
Employee & 98 & $55.36 \%$ \\
Duration of Work & 45 & $25.42 \%$ \\
1 - 2 year & & \\
$>$ 3 year & & \\
\hline
\end{tabular}

Source: Primary Data process (2021)

Table 1 presents respondent data with criteria including gender, age, job position, and length of time working at a coffee shop. Table 1 shows that male respondents are $69.49 \%$ dominant compared to male respondents. Based on age, respondents with an age range of $24-27$ years dominate by $61.58 \%$. This can be interpreted that people with this age range are in their productive age and focus on work. Based on the job position, $61.69 \%$ were dominated by positions as employees covering the shopping, barista, and service departments. This fact shows that the job positions that have been mentioned are directly related to operational activities, while for the long duration of working at the coffee shop, the period of $2-3$ years dominates by $55.36 \%$. The fact is that the emergence of a coffee shop in Indonesia is still relatively new, which has started operating in the past 5 years.

The measurement of model evaluation in this study can be carried out with 2 analyzes, namely the evaluation of the measurement model or better known as the outer model, and the measurement of the structural model or better known as the inner model. Steps that must be taken by the researcher are to test the validity and reliability test. Internal consistency measurements based on measurement reliability with alpha coefficient, composite reliability, and average variance extracted (AVE) for each construct were employed to assess validity. The purpose of the criterion is to demonstrate that the discriminant validity is acceptable. 


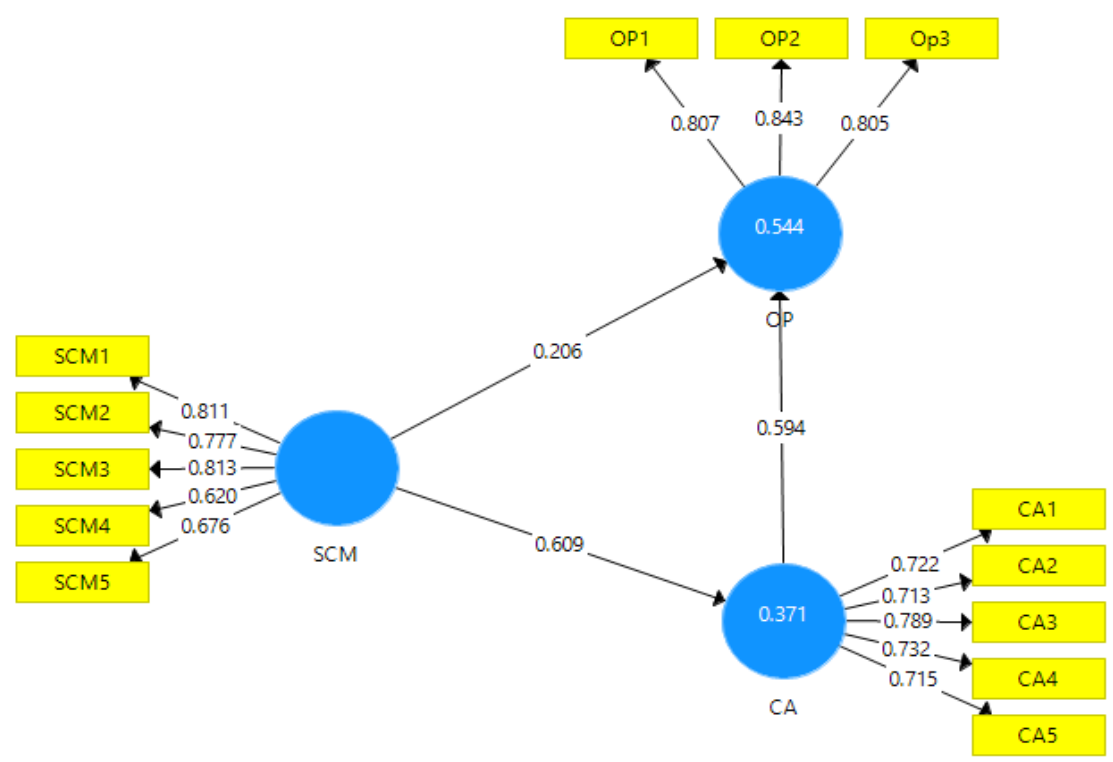

Figure 2. Data analysis using SmartPLS software

Table 2. Outer Loading dan Composite Reliability

\begin{tabular}{ccccc}
\hline Variabel & Indicator & Outer Loading & AVE & $\begin{array}{c}\text { Composite } \\
\text { Reliability }\end{array}$ \\
\hline & CA1 & 0.722 & & \\
Competitive & CA2 & 0.713 & & \\
Advantage & CA3 & 0.789 & 0.54 & 0.854 \\
(CA) & CA4 & 0.732 & & \\
Operation & CA5 & 0.715 & 0.859 \\
Performance & OP1 & 0.807 & & \\
(OP) & OP2 & 0.843 & & \\
& OP3 & 0.805 & & \\
SCM1 & 0.811 & & 0.862 \\
Manply Chain & SCM2 & 0.777 & & \\
(SCM) & SCM3 & 0.813 & & \\
\hline
\end{tabular}

Source: Primary Data process (2021)

Based on table 3, which presents the results of the evaluation of the outer model, all indicators in this study have an outer loading value and an average variance extracted (AVE) value> 0.5. According to Ghozali, (2013) the AVE value is expected to be greater than 0.5 if you want the research model to be said to be good. It can be concluded that all dimensions of the construct measurement are valid. Meanwhile, according to Chin, (2010), it is expected that the composite reliability value will be above 0.7 . It can be seen that the 3 variables used in this study have a composite reliability value $>0.7$

\section{Goodness of Fit Model}

This measurement is used to determine the extent of the inner model contained in this study. Each endogenous variable is stated by the R2 value, among others: (1) The endogenous variable competitive advantage has a value of 0.544 or $54.4 \%$ competitive advantage is influenced by supply chain management. (2) The endogenous variable operation performance has a value of 0.371 or $37.1 \%$ of the operation performance is influenced by competitive advantage and supply chain management. And the predictive relevance (Q2) value can be calculated as follows:

$$
\begin{aligned}
& \mathrm{Q} 2=1-(1-\mathrm{R} 12)(1-\mathrm{R} 22) \\
& \mathrm{Q} 2=1-(1-0.544)(1-0.371) \\
& \mathrm{Q} 2=1-(0.456)(0.629)
\end{aligned}
$$


$\mathrm{Q} 2=1-0.286$

$\mathrm{Q} 2=0.714$

The calculation above shows a high value of 0.714 so that the model is feasible to be declared to have a predictive-relevance value (Ghozali, 2013). The $71.4 \%$ result demonstrates the variety of data that the PLS model can explain, or the information contained in the data that the model can explain. Meanwhile, additional variables not included in the study explained $28.6 \%$ of the variance.

Table 3. Hypothesis Testing Results

\begin{tabular}{cccccc}
\hline & Coefficient & $\begin{array}{c}\text { Sample } \\
\text { Mean }(\mathrm{M})\end{array}$ & $\begin{array}{c}\text { T Statistics } \\
(|\mathrm{O} / \mathrm{STDEV}|)\end{array}$ & P -Values & Hypothesis \\
\hline CA -> OP & 0.594 & 0.591 & 9.784 & 0.000 & Supported \\
SCM -> CA & 0.609 & 0.616 & 13.217 & 0.000 & Supported \\
SCM -> OP & 0.206 & 0.209 & 3.133 & 0.002 & Supported \\
SCM -> CA-> OP & 0.362 & 0.364 & 8.226 & 0.000 & Supported \\
\hline
\end{tabular}

Source: Primary Data process (2021)

\section{Discussion}

Hypothesis 1: SCM on Operational Performance The path coefficient of 0.206 was achieved with a t statistic of 3.133 and a p-value of 0.002 when examining the effect of supply chain management on operational performance. The t statistic value of 3.1331 .96 and the p-value of 0.05 indicate that supply chain management has a substantial beneficial effect on coffee shop operational performance. The positive coefficient in this study is interpreted as a unidirectional relationship, which means that the better the supply chain management, the higher the operational performance of the coffee shop in Indonesia. The findings of this study support previous research by Althaqafi, (2020) that there is a strong relationship between SCM and operational performance and it impacts each other widely. Furthermore, this finding is in line with the research of (Phan et al., 2019; Duong et al., 2019) which revealed that maintaining supply chain management in the company has a good impact on operational performance. The findings of Vencataya et al., (2016) reinforce the findings of this study that effective SCM practices can have a good effect on operational performance in the company.

Hypothesis 2: The Effect of SCM on Competitive Advantage. Based on the results of the analysis conducted by the researcher, it was found that the coefficient value of the supply chain management path to competitive advantage was 0.609 . The statistical $t$ value obtained is 13,217 with a p-value of 0.00 . It can be interpreted that supply chain management has a significant positive effect on the competitive advantage at the coffee shop in Indonesia. The direction of a positive relationship shows that the existence of good supply chain management practices will result in the application of a good competitive advantage. This finding is supported by previous research by Vencataya et al., (2016) which explains that effective SCM practices can lead to better Supply Chain management which in turn can have a significant impact on competitive advantage. Effective supply chain management is a potentially valuable way of increasing competitive advantage in the company ( $\mathrm{Li}$ et al., 2006). Similar findings reveal that supply chain management practices have a positive effect on competitive advantage, but have no effect on firm performance (Sukati et al., 2012 ; Widyanesti \& Masyithah, 2018)

Hypothesis 3 : The Effect of Competitive Advantage on Operational Performance. The results of testing the effect of competitive advantage on operational performance have a path coefficient of 0.594 . The $t$ statistical value obtained is as wide as 9,784 with a p-value of 0,000 , this means that competitive advantage has a significant positive effect on operational performance at a coffee shop. The direction of a positive relationship indicates that competitive advantage can improve operational performance. The results of this study support the research conducted by (Boon-itt \& Pongpanarat, 2011; Camisón \& López, 2010) which reveals a positive relationship between competitive advantage and operational performance. Furthermore, the findings of this study are also supported by research conducted by (Kathuria et al., 2010) which proves that the application of competitive advantage which is devoted to quality has an impact on the company's operational performance. The same finding was also expressed by (Vencataya et al., 2016) with the existence of advantages. competing in a company has a good effect on operational performance.

Hypothesis 4 : The Effect of SCM on Operational Performance with Competitive Advantage as a mediator. The results of this study prove that competitive advantage is able to mediate the effect of supply chain management on the operational performance of a coffee shop pad in the city of Indonesia. The existence of a path coefficient 
of 0.362 has a positive impact with a competitive advantage for operational performance and supply chain management. The application of selecting strategies such as price, quality, delivery dependability, product innovation, and time to market is considered to be able to provide a good influence between supply chain management and operational performance at coffee shops in Indonesia. This finding supports several previous studies, such as Yuen and Van Thai, (2017) which states that there is a competitive advantage in a company linking supply chain management to company performance as represented by financial performance and operational performance. This is reinforced by the findings of Jumady and Hasbiyadi, (2016) which state that The impact of supply chain management on firm success is mediated through competitive advantage. An interesting finding in this research is that the existence of a competitive advantage gives a greater influence between supply chain management on operational performance at a coffee shop in Indonesia.

\section{Conclusion}

Based on the studies that have been carried out, the findings of this study include, among other things, that supply chain management on operational performance at coffee shops. Supply chain management is an integration of raw material procurement activities to end-users or in the form of services. The existence of a significant positive relationship implies that the better management of the existing supply chain at the coffee shop in Indonesia will result in higher operational performance. Competitive advantage has a significant positive effect on operational performance. Competitive advantage is understood as the company's ability to be different from others. The way a company is different is defined as something unique and can be used as a strategy in running its business at the coffee shop. A significant positive direction means that the better the application of competitive advantage results in higher operational performance at the coffee shop.

Furthermore, SCM has a significant positive effect on competitive advantage. The occurrence of a substantial positive association indicates that the better the present supply chain management at the coffee shop, the better the competitive advantage strategy that will be implemented. Competitive advantage serves as an excellent mediator for the impact of supply chain management on coffee shop operational performance. The use of various tactics to improve operational performance, which is influenced by supply chain management, is thought to be effective. Coffee shop owners should keep doing what they've done in the past, such as maintaining supply chain management to keep things running smoothly in the future. The implementation of competitive excellence needs to be maintained considering the impact it has on the operational performance of the coffee shop in Indonesia.

\section{References}

Althaqafi, T. (2020). The Impact of State-of-the-Art Supply Chain Management Practices on Operational Performance. International Journal of Supply Chain Management, 9(5), 1382-1391.

Boon-itt, S., \& Pongpanarat, C. (2011). Measuring Service Supply Chain Management Processes: The Application of the Q-Sort Technique. 2(3), 2-6.

Camisón, C., \& López, A. V. (2010). An examination of the relationship between manufacturing flexibility and firm performance: The mediating role of innovation. International Journal of Operations and Production Management, 30(8), 853-878. https://doi.org/10.1108/01443571011068199

Cooper, D., \& Schindler, P. (2013). Business Research Method: 12th Edition. Mcgraw-hill Us Higher.

Dikshit, P. S. K., \& Trivedi, D. S. (2012). Impact of Supply Chain Management Practices on Competitive Edge and Organisational Performance: Study of Cement Industry. Paradigm, 16(2), 67-81. https://doi.org/10.1177/0971890720120207

Duong, B. A. T., Truong, H. Q., Sameiro, M., Sampaio, P., Fernandes, A. C., Vilhena, E., Bui, L. T. C., \& Yadohisa, H. (2019). Supply chain management and organizational performance: the resonant influence. International Journal of Quality and Reliability Management, 36(7), 1053-1077. https://doi.org/10.1108/IJQRM-11-2017-0245

Fitrianto, A. Y., Sudaryanto, B., \& Manajemen, J. (2016). The Effect of Supply Chain Management on Outlet Operational Performance. Diponegoro Journal of Management, 5(2), 1-11.

Ghozali, I. (2013). Structural Equation Model Amos Concept \& Application 21.0. Badan Penerbit Universitas Diponegoro.

Hair, J. F., Black, W. C., Babin, B. J., \& E., A. R. (2014). Multivariate Data Analysis (7th ed.). Pearson Education Limited.

Heizer, J., \& Render, B. (2014). Operations Management (Sustainability and Supply Chain Management) (11th ed.). Salemba Empat. 
Jumady, \& Hasbiyadi. (2016). Mediating Role of Competitive Advantage on the Effect of Internal and External Supply Chain Integration in Efforts to Improve Small and Medium Enterprises Performance. Journal of Chemical Information and Modeling, 53(9), 123-133.

Kathuria, R., Porth, S. J., Kathuria, N. N., \& Kohli, T. K. (2010). Competitive priorities and strategic consensus in emerging economies: Evidence from India. International Journal of Operations and Production Management, 30(8), 879-896. https://doi.org/10.1108/01443571011068207

Khaddam, A. A., Irtaimeh, H. J., \& Bader, B. S. (2020). The effect of supply chain management on competitive advantage: The mediating role of information technology. Uncertain Supply Chain Management, 8(3), 547-562. https://doi.org/10.5267/j.uscm.2020.3.001

Kumar, V., Chibuzo, E. N., Garza-Reyes, J. A., Kumari, A., Rocha-Lona, L., \& Lopez-Torres, G. C. (2017). The Impact of Supply Chain Integration on Performance: Evidence from the UK Food Sector. Procedia Manufacturing, 11(June), 814-821. https://doi.org/10.1016/j.promfg.2017.07.183

Li, S., Ragu-Nathan, B., Ragu-Nathan, T. S., \& Subba Rao, S. (2006). The impact of supply chain management practices on competitive advantage and organizational performance. Omega, 34(2), 107-124. https://doi.org/10.1016/j.omega.2004.08.002

Marinagi, C., Trivellas, P., \& Sakas, D. P. (2014). The Impact of Information Technology on the Development of Supply Chain Competitive Advantage. Procedia - Social and Behavioral Sciences, 147, 586-591. https://doi.org/10.1016/j.sbspro.2014.07.161

Miguel, P. L. de S., \& Brito, L. A. L. (2011). Supply Chain Management measurement and its influence on Operational Performance. Journal of Operations and Supply Chain Management, 4(2), 56. https://doi.org/10.12660/joscmv4n2p56-70

Phan, A. C., Nguyen, H. A., Trieu, P. D., Nguyen, H. T., \& Matsui, Y. (2019). Impact of supply chain quality management practices on operational performance: empirical evidence from manufacturing companies in Vietnam. Supply Chain Management, 24(6), 855-871. https://doi.org/10.1108/SCM-12-2018-0445

Republika. (2020). Tiga Dampak Besar Pandemi Covid-19 bagi Ekonomi RI.

Subhan, A., \& Putro, B. E. (2017). Supply Chain and Quality Management Practice: Its Impact on Competitive Advantage and Firm Performance (Study on Small and Medium Enterprises at West Java). Jurnal Manajemen Teknologi, 16(3), 222-240. https://doi.org/10.12695/jmt.2017.16.3.1

Sukati, I., Abdul Hamid, A., Baharun, R., Alifiah, M., \& Ahmad Anuar, M. (2012). Competitive advantage through supply chain responsiveness and supply chain integration. International Journal of Business and Commerce, 1(7), 1-11.

Tjiptono, A. (2017). Service management (3rd ed.). Andi.

Vencataya, L., Seebaluck, A. K., \& Doorga, D. (2016). Assessing the impact of supply chain management on competitive advantage and operational performance: A case of four star hotels of Mauritius. International Review of Management and Marketing, 6(4), 61-69.

Widyanesti, S., \& Masyithah, S. (2018). The Influence of Supply Chain Management Practices and Marketing Capability on Firm Performance Through Competitive Advantage. Mix: Jurnal Ilmiah Manajemen, 8(2), 208. https://doi.org/10.22441/mix.2018.v8i2.002

Yuen, K. F., \& Van Thai, V. (2017). The influence of supply chain integration on operational performance: A comparison between product and service supply chains. International Journal of Logistics Management, 28(2), 444-463. https://doi.org/10.1108/IJLM-12-2015-0241

\section{Copyrights}

Copyright for this article is retained by the author(s), with first publication rights granted to the journal.

This is an open-access article distributed under the terms and conditions of the Creative Commons Attribution license (http://creativecommons.org/licenses/by/4.0/). 